\title{
Increasing Public Understanding of Disaster By Way of Educational Tourism in Pangandaran, Indonesia
}

\author{
Priyo Subekti ${ }^{1}$, Hanny Hafiar ${ }^{2}$, Iriana Bakti ${ }^{3}$ \\ \{priyo.subekti@unpad.ac.id ${ }^{l, h a n n y h a f i a r @ g m a i l . c o m}{ }^{2}$,Irianabaktipr@gmail.com ${ }^{3}$ \} \\ Universitas Padjadjaran, Indonesia ${ }^{1,2,3}$
}

\begin{abstract}
Pangandaran is an environment-based tourist destination which is quite popular in Indonesia, but Pangandaran has a high potential for disaster. The purpose of this article is to find out how the efforts made by the Regional Disaster Management Agency (BPBD) of Pangandaran Regency to increase public understanding of disaster through educational tours to schools. This study uses descriptive methods that are supported by qualitative and quantitative data as reinforcement. The collection of qualitative data is carried out through the following techniques: 1) Key Informant Interview. This interview comprises a series of open-ended questions conducted on individuals who are considered to have knowledge and experience regarding education, tourism programs in the community regarding disaster mitigation; 2) Direct observation which is carried out through field trips and to community activities is in line with the research objectives. Data collected in the form of information on geographical, socioeconomic conditions, available resources, and ongoing program activities. The results of the study illustrate how the role of disaster education is packaged under the name of Disaster Education Tourism Goes To School (WEB GTS) to build a safety and resilience culture in society. The provision of disaster education to school children aims to provide them with sufficient skills and knowledge to manage disasters. With the support of sufficient knowledge and a supportive environment, children have the potential to become agents who are able to do independent rescue and can be a media for transferring disaster knowledge to their immediate environment, especially in the family.
\end{abstract}

Keywords: disaster mitigation; educational tourism; socialization; tourist destinations; education

\section{Introduction}

Indonesia is a country with a high potential for disasters, with the tectonic order of the Indonesian archipelago. Plate boundaries that have high seismicity which causes a high probability of earthquakes that can cause tsunamis in Indonesia [1]. With such natural and environmental conditions, it is necessary to have a disaster management system that starts from the early warning system, disaster events, and post-disaster. In addition, there is a study that suggests that current climate change can exacerbate and increase natural disasters more often and more such as floods, droughts, heat waves, and forest fires, increasing in frequency and intensity in many parts of the world putting populations at greater risk on events and their effects [2] [3].

Based on data held by the Indonesian National Disaster Management Agency (BNPB), it is noted that in 2018 there have been 1,999 natural disasters, and according to BNPB, the number is predicted to continue to increase. Natural disasters can have a very large impact, it 
is recorded that around 3,548 people died and disappeared, 13,112 people suffered injuries. Around 3.06 million people were displaced, and the disaster caused enormous damage to public facilities and residential areas, which resulted in the community having to evacuate [4]. Basically, all types of disasters, whether caused by nature, human activity, and / or both, such as earthquakes, tsunamis, volcanic eruptions, floods, landslides, droughts, forest fires / haze disasters, pest outbreaks, and disasters because of industrial accidents and technological failures, always threatening the lives of the Indonesian people. Disasters [5].

The impact of the disaster which caused damage to housing and public facilities that caused considerable losses in the economic field, the following is a data of 2020 natural disasters in Indonesia:

Table 1. Indonesia Natural Disasters in 2020

\begin{tabular}{llllllll}
\hline \multicolumn{1}{c}{ Table 1. Indonesia Natural Disasters in 2020 } \\
\hline No & $\begin{array}{l}\text { Number } \\
\text { of } \\
\text { events }\end{array}$ & Fatalities & $\begin{array}{l}\text { Casualties } \\
\text { Damage } \\
\text { to Houses }\end{array}$ & $\begin{array}{l}\text { Damage } \\
\text { to } \\
\text { Worship } \\
\text { Facilities }\end{array}$ & $\begin{array}{l}\text { Damage } \\
\text { Education } \\
\text { Facilities }\end{array}$ & $\begin{array}{l}\text { Damage } \\
\text { Health } \\
\text { Facilities }\end{array}$ \\
\hline 1 & Landslides & 726 & 18 & 435 & 7 & 9 & 2 \\
2 & Flood & 556 & 58 & 9907 & 50 & 69 & 13 \\
3 & Tornado & 452 & 6 & 3964 & 15 & 21 & 4 \\
4 & Forest / Land Fires & 102 & 0 & 0 & 0 & 0 & 0 \\
5 & Wave / Abrasion & 18 & 0 & 28 & 0 & 0 & 0 \\
6 & Earthquake & 11 & 0 & 1 & 0 & 1 & 0 \\
7 & Volcanic Eruption & 7 & 0 & 0 & 0 & 0 & 0 \\
8 & Drought & 1 & 0 & 0 & 0 & 0 & 0 \\
\hline & total & 1873 & 82 & 14335 & 72 & 100 & 19 \\
\hline
\end{tabular}

From the table above, it can be seen that the potential for disasters in Indonesia is quite large, the impact caused by disasters can affect the economic sector as a whole. With the high number of disasters in the country, unfortunately currently Indonesia does not have disaster mitigation standards like in Japan, Australia or the United States [6]. With the high potential for disasters in Indonesia, the community needs to be equipped with disaster knowledge, especially for disaster education, disaster emergency, and post-disaster management.

According to the Chief Executive of the Regional Disaster Management Agency (BPBD), Pangandaran Regency is a disaster-prone region with 16th rank out of 514 districts/cities in Indonesia, while disaster infrastructure is still very minimal. When viewed from the standard of disaster equipment, Pangandaran is still far from the standard, compared to 27 districts/cities in West Java, it can be said that Pangandaran is far from ideal in terms of disaster infrastructure, this is because BPBD Pangandaran has just been established and the capability of the regency is not yet optimal.

Communities threatened by disasters are very diverse, both educated and still untouched by education all need to be given an understanding of the importance of disaster risk reduction, and one way is through disaster mitigation education that can be implemented through formal and non-formal education channels. Disaster education has a strategic role in providing disaster education and mitigation in the midst of society because it can reach various groups and groups of people [7].

With the high potential for disasters in Pangandaran, it is felt that there is a need for disaster mitigation education in the community, especially in early education. The extraordinary impact of disasters so far has been caused more often by the lack of awareness and understanding of the community towards potential disaster vulnerabilities and mitigation in an effort to reduce the impact. Mitigation is part of pre-disaster activities, while pre-disaster 
is part of the disaster management cycle. Disaster education is very important in building a culture of safety and resilience in society [8]. By using mitigation education, BPBD can overcome differences in perceptions and confusion of information related to disasters ranging from floods, earthquakes, and tsunamis. For example disaster, when an earthquake occurs, people should go outside the house to a flat area such as a field instead of hiding under a table, because it would be very dangerous, the table could not hold material that fell from above and instead would narrow the space for individuals underneath. In addition, one of the other important points is the post-disaster phase, because at that time the conditions were not controlled and help would not necessarily come quickly so that the psychological state of the community was very critical [9]. Preparedness is an action taken in the pre-disaster period (before the disaster occurs) [10]. The purpose of disaster preparedness is to reduce the risk (impact) caused by the disaster.

In an effort to overcome the unclear information about the disaster, the BPBD conducts training through disaster education for junior and elementary school students, as well as housewives. Disaster management through disaster mitigation education is expected to provide knowledge and understanding to the participants by the media, such as radio, outdoor media and through the training of disaster demonstration

\section{Literature Review}

Several studies on disaster education in school children show significant results, according to Proulx and Aboud [11] which conducts research on Disaster Risk Reduction (DDR) for preschool children (for example under 6 years), disaster education for children has the potential to reduce the risk and impact of natural disasters by increasing the quality of knowledge of pre-school children, because children are very vulnerable to disasters that can pose a threat to physical health, and psychological disorders. One of the best ways to protect children is to build a culture of disaster risk reduction whereby receiving information about disaster children are aware of the surrounding danger and have the ability to deal with it.

Other research emphasizes the importance of disaster education to improve community understanding so that they are able to deal with disasters wisely. A survey was conducted involving 152 nurses as respondents whose results show that nurses in South Australia consider themselves to have a low level of disaster preparedness. Due to limited education and experience in response to disasters which ultimately decreased confidence among nurses in South Australia. 95\% of nurses agree that disaster emergency education for nurses is important, $39 \%$ of participants have never had disaster training, while $63 \%$ of participants have never been involved in disaster education [12]. To get effective results in both physical and non-physical Disaster Risk Reduction (DRR) programs, formal education will not be sufficient due to the complexity of the problem [13].

There are several stages of disaster mitigation, namely: 1) Disaster Risk Reduction (DRR) which aims to reduce damage caused by natural hazards such as earthquakes, floods, drought, and cyclones, through an ethic of prevention; 2) Disaster Risk Management; Includes management activities which deal with and seek to improve or reduce the risk of disasters that exist or have occurred [14].

In the simplest terms, mitigation means reducing the possibility of damage that can cause very large casualties both fatalities and material. Besides mitigation also means an effort made by the government or related institutions to ensure the continuity of public facilities that can 
support refugees when a disaster occurs, or can also be defined as an economic recovery effort because of natural disasters caused or also an effort to provide education to the public about disaster. Mitigation is defined as any ongoing action taken to reduce or eliminate the longterm risk to human assets and lives. Therefore, mitigation can be said as a mechanism so that people can avoid the impact of potential disasters. Actions taken can focus on disaster avoidance, specifically avoiding the placement of people and property in hazardous areas [15]. This is reinforced that the damage caused by natural disasters has an impact on the economy, people's lives, and the environment (Lin and Jia 2012). The complexity that develops from the disaster problem will impact on the environment and people's lives, and will also affect people's behavior both socially and economically [16].

Mitigation training can be done through education to give the community the ability to become accustomed to dealing with disasters, especially in the Pangandaran area so that the community becomes alert and does not panic if a disaster occurs [17]. Educational activities can have a strategic impact in the long term if education is carried out in early childhood (elementary, junior high school students), from an early age, children already have the knowledge and ability to deal with disasters, in addition, it is assumed that children quickly absorb the lessons given.

According to Oepen and Hamacher [18], environmental communication is a planned communication process using media products to support effective policy formulation, community participation, and activities directed at environmental sustainability. Environmental communication has the aim of shaping the ability of the community to respond to signals from the environment appropriately and use them for the welfare and security of humans. They use environmental communication as a communication strategy that makes it easy for people who receive and understand the information in responding to the activities carried out by the government, in this case, BPBD related to education or disaster mitigation [19].

\section{Methodology}

This study aims to find out how the efforts made by the Pangandaran Regency BPBD in improving public understanding of disaster through educational tourism. Pangandaran is a disaster-prone area so government efforts are needed in dealing with potential disasters that will occur, especially in strengthening the pre-disaster stage. This study uses descriptive methods that are supported by qualitative and quantitative data as reinforcement.

Qualitative data retrieval was conducted through two techniques which are: 1) Key informant interviews (Key Informant Interview). This interview consists of a series of openended questions conducted on individuals who are considered having knowledge and experience regarding education tourism programs in the community regarding disaster mitigation; 2) Direct observation is carried out through field visits and community activities are in line with the research objectives. Data collected in the form of information about geographical, socio-economic conditions, available resources, and ongoing program activities.

The key informant determination technique is conducted by the purposive method. The key informant criteria set out in this study include: directly involved in disaster mitigation education tourism activities which include: the head of BPBD as the main resource person, presenters in disaster mitigation education activities and participants. The validity of the data 
uses a triangulation technique that is conducting interviews with the same source through different methods and times, as well as observing non-participation in some time.

\section{Result and Discussion}

Pangandaran is a tourist destination that is able to attract tourists, both domestic and foreign tourists. Pangandaran has beach locations that have the potential to become leading tourist attractions ranging from Karang Mini then Lembah Putri, West Coast, East Coast, Batu Hiu, Batu Karas, to Madasari. Having good tourism potential, this is a positive thing for the Pangandaran community, but Pangandaran also has a large potential for natural disasters ranging from earthquakes, tsunamis, floods, landslides, droughts, fires, and whirlwinds.

According to the Head of BPBD Pangandaran, the most difficult thing was to prepare for disaster preparedness to face the Tsunami, because the Tsunami was the most severe of all types of disasters. 10 years ago, on July 17, 2006, Pangandaran was hit by a tsunami that caused enormous damage and caused around 668 deaths and 9,299 injured. Unlike the 2004 Aceh tsunami, the Pangandaran tsunami was not preceded by a strong earthquake that could be a sign for the community of potential tsunamis. When discussing disaster management, there are three cycles of disaster management, namely in pre-disaster, disaster emergency and post-disaster. Among the three cycles, the greatest impact is a disaster emergency. Usually, in the event of a disaster, the first thing people look for is BPBD, BNPB, the government, logistical assistance, accommodation assistance, food supplies, temporary shelter, and the community will be angry if aid arrives late.

During a disaster emergency, the first step taken is to rescue and evacuate. After that, fulfillment basic needs, for example, making refugee locations that are equipped with basic needs ranging from eating, drinking, sleeping in refugee camps, including other specific needs based on age and gender. For the post-disaster stage, rehabilitation of public facilities and infrastructures is carried out, then thinking about their economic and psychological conditions (trauma healing).

In implementing disaster management, the first stage is pre-disaster, namely the situation or situation when there is no disaster and the situation when there is a potential for disaster. At this stage, one of the first steps taken is to make disaster planning, for example, if a landslide occurs, then it must determine which points are prone to landslides, then determine the evacuation road points, determine the evacuation sign points and so on. One of the pre-disaster mitigation activities includes preparing land use, the environment, transportation systems that can be a support system when disasters occur [20] [21]. This is a challenge for the government to be able to manage and prepare for disaster preparedness including infrastructure, public facilities, evacuation routes and transportation systems [22].

For Pre-Disasters, disaster mitigation is carried out starting from elementary school children, communities and students where they must be prepared to face disasters must understand what they must do when a disaster occurs. Disaster mitigation activities in the predisaster stage are carried out through disaster education to the community. Education is a surefire strategy as one pillar in the effort to build a resilient Indonesian society in the face of disasters [5]. The objectives of disaster education itself include: building a culture of safety context within the community and government, equating perceptions about disasters, and providing knowledge about disasters that will ultimately create disaster-resistant communities that are able to act appropriately and quickly when disasters occur. Furthermore, regarding the 
current state of disaster education, it can be said that there is still a lack of knowledge and understanding of the community regarding disaster risk reduction knowledge and a lack of guidance or teaching material on the disaster that can be accessed by the public [5].

With education on disasters, in this case, an earthquake, it can be used as social capital for the community when the threat of an earthquake comes again. At present, the earthquake is a threat that is difficult to predict [23]. One important point in disaster mitigation is resilience, namely the resilience and adaptability of the community to pressure, the pressure, in this case, is the condition after the disaster occurred [24]. After a disaster strikes, it is very likely that people will lose their homes, workplaces and public facilities, at such times there will usually be many people who experience depression, illness, stress, and loss. In general, community resilience in dealing with the effects of disasters is because they have no choice but to stay in that place because it is only their place of residence and for other reasons, they feel they have an attachment to their place of residence.

\subsection{Disaster Education Tourism Goes To School (WEB GTS) Program}

Disaster socialization is carried out directly to schools and named the Disaster Education Tourism Goes To School (WEB GTS) Program. This program was first carried out in 2016, in collaboration with the education office, to provide material for an introduction to disasters and how to deal with them. Not only that, but the BPBD also has a program named Mother Learning Mitigation (BBM). In every case of disaster, children are a group that is vulnerable to being affected by disasters. Natural disasters often cause significant injury, loss of life, and property damage. Although physical and mental consequences are not limited to certain segments of society, children may be very vulnerable and it is very likely that this natural disaster can affect children's mental health outcomes and can affect their psychological development into adulthood [25]. This is due to the lack of knowledge they have about saving themselves and their physical abilities are also very limited. This is what later encouraged the Operational Control Center (Pusdalops) of the Pangandaran District Disaster Management to create a disaster education program for children.

There are several reasons why choosing kindergarten children and housewives as targets of mitigation education include: children are assumed to absorb knowledge quickly, in contrast to parents. Children are given knowledge through simulations and media images because children can remember more quickly if knowledge is given through motor and visual motion. There is a story that is quite interesting, that kindergarten children who have been given mitigation education sometimes provide knowledge to their parents about how to deal with the leaky gas, rescue when an earthquake occurs and the evacuation route that must be passed when a disaster is happening. While the reason mothers are targeted is that mothers are the riskiest and easy to panic when facing a disaster.

Disaster Education Tourism Goes To School (WEB GTS) Program has brought positive changes in managing disasters in Pangandaran Regency. Following the community trend, the BPBD uses social media networks to facilitate communication and provide disaster information to the public, through the Instagram account@pusdalopspangandaran, and through social media Facebook.

Currently, the WEB GTS Team has educated 1,080 students from 21 elementary schools in Pangandaran Regency, as an effort to shape the nation's future character, a community that is resilient to face disasters and become a disaster risk reduction movement. This program does not burden schools in terms of cost, because they only need to register, and then wait for the agenda to be visited by the WEB GTS Pusdalops PB team of Pangandaran Regency. 
The provision of disaster education to school children aims to provide them with sufficient skills and knowledge to manage disasters. With the support of sufficient knowledge and a supportive environment, potential children become agents who are able to do an independent rescue.

Educational activities are delivered with a special method with the concept of adventure to recognize disaster. This is done so that children feel joy and happiness, but able to easily understand conveyed disaster knowledge. Children are introduced to the types of disasters, following how to deal and preventive measures to deal with disasters, and then also introduced disaster equipment. In addition, they were also invited to see disaster education films that were packaged into a light show in the form of animated films. Providing education through disaster animated films, such as Tsunamis, Earthquakes, Floods, Landslides, tornadoes and other disasters and the delivery of relaxed and cheerful material that makes students able to understand the material well. In the final session of activities, children are invited to play disaster outbound.

Some educational materials taught by BPBD to elementary and junior high school students and housewives include disaster knowledge, especially earthquakes, namely: 1) defining earthquakes, explaining the causes of earthquakes; 2) explain and categorize the impact caused by an earthquake; 3 ) identify how to save themselves when an earthquake occurs, explain the correct procedure to save from an earthquake and do a rescue simulation when an earthquake occurs; 4) create a map and evacuation route when an earthquake occurs and recognize a safe area to be used as an evacuation site.

\section{Conclusion}

Pangandaran Regency is a disaster-prone area, but disaster infrastructure is still very minimal, far from ideal if it is associated with the disaster infrastructure. With the high potential for disasters in Pangandaran, it is felt the need for disaster mitigation education in the community especially early education. The extraordinary impacts of disasters so far have been caused more often by the lack of awareness and understanding of the community towards potential disaster vulnerabilities and mitigation in reducing their impact.

Disaster education is very important to build a culture of safety and resilience in the community. Therefore, the BPBD conducted socialization on disasters carried out directly to schools, named the Goes To School Disaster Education Tourism program (WEB GTS). This program was first carried out in 2016 , in collaboration with the education office to provide material on introduction to disasters and how to deal with them. The program was made not only that, but the BPBD also has a program called the Mother Learning Mitigation (BBM). The hope of this activity is to instill an awareness of disasters in children so they can be media for transferring disaster knowledge to their immediate environment, especially in the family

\section{References}

[1] I. G. Tejakusuma, “Analisis Pasca Bencana Tsunami Ciamis - Cilacap,” J. Sains dan Teknol. Indones., vol. 10, no. 2, pp. 78-83, 2012.

[2] H. Hu, T. Lei, J. Hu, S. Zhang, and P. Kavan, "Disaster-mitigating and general innovative responses to climate disasters: Evidence from modern and historical China," Int. J. Disaster 
Risk Reduct., vol. 28, no. August 2017, pp. 664-673, 2018, doi: 10.1016/j.ijdrr.2018.01.022.

[3] J. Raikes, T. F. Smith, C. Jacobson, and C. Baldwin, "Pre-disaster planning and preparedness for floods and droughts: A systematic review," Int. J. Disaster Risk Reduct., vol. 38, no. May, p. 101207, 2019, doi: 10.1016/j.ijdrr.2019.101207.

[4] F. C. Farisa, "BNPB: Selama 2018, Ada 1.999 Kejadian Bencana," Kompas.com, 2018. https://nasional.kompas.com/read/2018/10/25/22572321/bnpb-selama-2018-ada-1999-kejadianbencana.

[5] J. Maknun, "Pembelajaran Mitigasi Bencana Berorientasi Kearifan Lokal Pada Pembelajaran IPA Di Sekolah Menengah Kejuruan,” J. Kaji. Pendidik., vol. 5, no. 1, pp. 143-156, 2015.

[6] M. Nadlir, "BNPB: Indonesia Belum Punya Standar Mitigasi Bencana seperti Jepang," Kompas.com, 2018. https://nasional.kompas.com/read/2018/03/05/19501381/bnpb-indonesiabelum-punya-standar-mitigasi-bencana-seperti-jepang.

[7] V. Sunarti, "Peranan Pendidikan Luar Sekolah Dalam Rangka Mitigasi Bencana," Spektrum J. Pendidik. Luar Sekol., vol. 2, no. 2, 2014, doi: 10.24036/spektrumpls.v2i2.5044.

[8] L. Zhou, S. Perera, J. Jayawickrama, and O. Adeniyi, "The Implication of Hyogo Framework for Action for Disaster Resilience Education," Procedia Econ. Financ., vol. 18, no. September, pp. 576-583, 2014, doi: 10.1016/s2212-5671(14)00978-2.

[9] B. Andrea and M. Michele, "Influence rather than control: A new approach for disaster education in the immediate aftermath of a disaster," Int. J. Disaster Risk Reduct., vol. 19, pp. 112-117, 2016, doi: 10.1016/j.ijdrr.2016.08.026.

[10] M. Widjanarko and U. Minnafiah, "Pengaruh Pendidikan Bencana Pada Perilaku Kesiapsiagaan Siswa," J. Ecopsy, vol. 5, no. 1, p. 1, 2018, doi: 10.20527/ecopsy.v5i1.4878.

[11] K. Proulx and F. Aboud, "Disaster risk reduction in early childhood education: Effects on preschool quality and child outcomes," Int. J. Educ. Dev., vol. 66, no. October 2017, pp. 1-7, 2019, doi: 10.1016/j.ijedudev.2019.01.007.

[12] K. Duong, "Disaster education and training of emergency nurses in South Australia," Australas. Emerg. Nurs. J., vol. 12, no. 3, pp. 86-92, 2009, doi: 10.1016/j.aenj.2009.05.001.

[13] D. Suhardjo, "Arti Penting Pendidikan Mitigasi Bencana Dalam Mengurangi Resiko Bencana," J. Cakrawala Pendidik., no. 2, pp. 174-188, 2015, doi: 10.21831/cp.v0i2.4226.

[14] R. M. Gougelet, Disaster Mitigation, 2nd ed. Elsevier Inc., 2006.

[15] P. Studi, I. Komunikasi, F. Universitas, and A. Azhar, "Wilayah Rawan Bencana Gunung Merapi," J. ASPIKOM, vol. 2, no. 3, pp. 179-197, 2014.

[16] C. Jaca, V. Prieto-Sandoval, E. L. Psomas, and M. Ormazabal, "What should consumer organizations do to drive environmental sustainability?," J. Clean. Prod., vol. 181, pp. 201-208, 2018, doi: 10.1016/j.jclepro.2018.01.182.

[17] A. Rusilowati, Supriyadi, A. Binadja, and S. E. S. Mulyani, "Mitigasi Bencana Alam Berbasis Pembelajaran Bervisi Science Environment Technology and Society," J. Pendidik. Fis. Indones. (Indonesian J. Phys. Educ., vol. 8, no. 1, pp. 51-60, 2012.

[18] P. Lestari, E. T. Paripurno, S. B. Kusumayudha, and B. Ramadhaniyanto, "Erupsi Gunung Sinabung," J. ASPIKOM, vol. 3, no. 1, pp. 56-64, 2016.

[19] I. Bakti, H. Hafiar, H. R. Budiana, and L. Puspitasari, "Komunikasi Lingkungan: Menakar Pelibatan Peran," Kawistara, vol. 7, no. 1, pp. 94-107, 2017.

[20] F. Fahmi, P. Timms, and S. Shepherd, "Integrating Disaster Mitigation Strategies in Land Use and Transport Plan Interaction," Procedia - Soc. Behav. Sci., vol. 111, pp. 488-497, 2014, doi: 10.1016/j.sbspro.2014.01.082.

[21] S. Iizuka, Y. Xuan, and Y. Kondo, "Impacts of disaster mitigation/prevention urban structure models on future urban thermal environment," Sustain. Cities Soc., vol. 19, pp. 414-420, 2015, doi: $10.1016 / j . s c s .2015 .06 .008$.

[22] P. Tang, Q. Xia, and Y. Wang, "Addressing cascading effects of earthquakes in urban areas from network perspective to improve disaster mitigation," Int. J. Disaster Risk Reduct., vol. 35, p. 101065, 2019, doi: 10.1016/j.ijdrr.2019.101065.

[23] I. W. Subagia, "Pelatihan Mitigasi Bencana Alam Gempa Bumi Pada Siswa Sekolah Dasar Negeri 1 Pengastulan Kecamatan Seririt Kabupaten Buleleng Bali," JPI (Jurnal Pendidik. 
Indones., vol. 4, no. 1, pp. 585-598, 2017, doi: 10.23887/jpi-undiksha.v4i1.4916.

[24] N. Ariviyanti and W. Pradoto, "Faktor-Faktor Yang Meningkatkan Resiliensi Masyarakat Dalam Menghadapi Bencana Rob Di Kelurahan Tanjung Emas Semarang,” J. Tek. PWK, vol. 3, no. 4, 2014.

[25] J. C. Maclean, I. Popovici, and M. T. French, "Are natural disasters in early childhood associated with mental health and substance use disorders as an adult?," Soc. Sci. Med., vol. 151, no. 2016, pp. 78-91, 2016, doi: 10.1016/j.socscimed.2016.01.006. 